\title{
Legacies for the Common Good
}

\author{
James Morton Turner
}

In the past decade, numerous scholars and activists have highlighted the environmental movement's roots in white privilege. The activist Van Jones described the environmental movement as "affluent and lily white" and noted its failures to challenge the nation's racial status quo. ${ }^{1}$ The geographer Carolyn Finney echoed that point, explaining that the "environment" has been a synonym for the "outdoors," and that, historically, the environmental movement has "legitimate[d] the invisibility of the African American in the Great Outdoors and in all spaces that inform, shape, and control the way we know and interact with the environment in the United States." ${ }^{2}$ These critics and scholars are among many who have argued that protecting wild and suburban landscapes has come at the expense of the poor and minorities, as the burdens of pollution and environmental degradation have been shifted to disadvantaged communities, neighborhoods, or other countries. ${ }^{3}$ The scholars Lisa Sun-Hee Park and David Pellow have advanced this point most stridently, describing a culture of "nativist environmentalism"-preoccupied with overpopulation and concerned with protecting environmental amenities for the privileged, usually "white," few. ${ }^{4}$ Underlying these critiques is the argument that "mainstream" American environmentalism is hampered by its narrowness: focused on nature protection, rooted in white privilege, and complicit in a consumer culture that favors the well-to-do who can afford organic vegetables, hybrid vehicles, and suburban homes.

Evidence-both historical and contemporary-substantiates aspects of this critique. American conservation and preservation movements in the early twentieth century were steeped in nativism and racism. ${ }^{5}$ In the 1960 s, luminaries like Rachel Carson focused more on the threat that pesticides posed to wildlife and children than to Latino farm workers. Wilderness advocates championed setting aside wild places "where man himself is a visitor who does not remain," largely ignoring Native Americans' historical claims to and cultural and political interests in such lands. ${ }^{6}$ Leading activists such as Paul Ehrlich described a global population bomb in the

The author appreciates the helpful feedback on this essay he received from Drew Isenberg, Matt Klingle, Tom Robertson, and Jennifer Thomson.

${ }^{1}$ Van Jones, “Beyond Eco-Apartheid," Ella Baker Center, Apr. 30, 2007, http://ellabakercenter.org/in-the-news/ newsop-ed-news-story/beyond-eco-apartheid (accessed Jun. 24, 2017).

${ }^{2}$ Carolyn Finney, Black Faces, White Spaces: Reimagining the Relationship of African Americans to the Great Outdoors (Chapel Hill, NC, 2014), 4-5.

${ }^{3}$ Others who have advanced similar arguments include Laura Pulido, "Rethinking Environmental Racism: White Privilege and Urban Development in Southern California," Annals of the Association of American Geographers 90, no. 1 (2000): 12-40; Julie Guthman, “If They Only Knew': The Unbearable Whiteness of Alternative Food," in Cultivating Food Justice: Race, Class, and Sustainability, eds. Alison Hope Alkon and Julia Agyeman (Cambridge, MA, 2011), 263-282; and Matthew Klingle and Jay Taylor, "Caste from the Past: Environmentalism's Elitist Tinge Has Roots in the Movement's History," Grist, Mar. 8, 2006, https://grist.org/article/klingle/ (accessed Nov. 1, 2017).

${ }^{4}$ Lisa Sun-Hee Park and David N. Pellow, The Slums of Aspen: Immigrants vs. the Environment in America's Eden (New York, 2011), 11-12, 15.

${ }^{5}$ Dorceta E. Taylor, The Rise of the American Conservation Movement: Power, Privilege, and Environmental Protection (Chapel Hill, NC, 2016); Jedediah Purdy, “Environmentalism's Racist History,” New Yorker, Aug. 13, 2015, https://www.newyorker.com/news/news-desk/environmentalisms-racist-history (accessed Nov. 1, 2017).

${ }^{6}$ Mark David Spence, Dispossessing the Wilderness: Indian Removal and the Making of the National Parks (New York, 1999); Dorceta E. Taylor, The Rise of the American Conservation Movement: Power, Privilege, and Environmental Protection (Durham, NC, 2016).

(c) The Author(s) 2018. Published by Cambridge University Press 
1960s, starting his best-selling book with the specter of rapidly growing populations of poor colored people in developing countries. ${ }^{7}$ Some white middle-class suburbanites in Gary, Indiana, rallied to the campaign to protect the Indiana Dunes Lakeshore in the 1970s in the hopes of keeping blacks out of their neighborhood. ${ }^{8}$ There was a shift toward more consumer-based action after the 1970s, exemplified by green consumerism. ${ }^{9}$ And, lastly, both historically and today, the top leaders of national environmental groups are overwhelmingly white and predominantly male. ${ }^{10}$

Yet there is also much evidence that complicates this narrative of mainstream environmentalism. Paul Ehrlich spoke forcefully about the disproportionate responsibility whites bore for the world's environmental ills and the disproportionate risks urban and minorities faced from pollution. ${ }^{11}$ Some environmentalists, although not all, provided support for Native Alaskans in their campaigns to secure land holdings and subsistence access to protected areas such as wilderness and parks. ${ }^{12}$ Working-class white people in Appalachia spearheaded local campaigns to resist strip mining for coal and protect their rural communities. ${ }^{13}$ Scientists and lawyers at groups such as the Environmental Defense Fund and the Natural Resources Defense Council fought to eliminate lead contamination and ensure safe drinking water. And some of the fiercest battles over laws like the Clean Air Act have centered around regulating other heavy metals, such as mercury, which disproportionately affect people of color and Native Americans. Although critics often fault environmentalists for being "motivated largely by their veneration for the wild" or an "ideological fixation on population control," a good deal of the concern, mobilization, and litigation that has occupied modern environmental politics since the 1970s has focused not on those issues, but rather, issues of pollution and public health. ${ }^{14}$

Reading the early literature on the history of the modern American environmental movement and its antecedents would have done little to highlight this broader and more complicated narrative of environmentalism, however. That early generation of scholars tended to focus on organizations such as the Sierra Club, the campaigns to protect places such as the Grand Canyon, and the leadership of scientist-activists such as Rachel Carson. Roderick Nash's history Wilderness the American Mind (1967) positioned wilderness as the formative concept in American environmental thought and activism, with little attention to the interests of either Native Americans or rural Americans. ${ }^{15}$ In The American Conservation Tradition (1981), Stephen Fox traced the progression from concerns over wilderness and wildlife in the early twentieth century to a "man-centered conservation" focused on human welfare launched by Carson's Silent Spring. ${ }^{16}$ Samuel Hay's classic history Beauty, Health, and Permanence (1987) further described the rise of modern environmentalism as a product of the post-war

\footnotetext{
${ }^{7}$ For careful analysis of The Population Bomb (1968) and Ehrlich's positions, see Thomas Robertson, The Malthusian Moment: Global Population Growth and the Birth of American Environmentalism (New Brunswick, NJ, 2012).

${ }^{8}$ Andrew Hurley, Environmental Inequalities: Class, Race, and Industrial Pollution in Gary, Indiana, 1945-1980 (Chapel Hill, NC, 1995), 70-73.

${ }^{9}$ Michael F. Maniates, "Individualization: Plant a Tree, Buy a Bike, Save the World?," Global Environmental Politics 1, no. 3 (Aug. 2001): 31-52.

${ }^{10}$ See Green 2.0 's reports on diversity and staffing at http://www.diversegreen.org.

${ }^{11}$ Robertson, The Malthusian Moment, 178-81.

${ }^{12}$ James Morton Turner, The Promise of Wilderness: American Environmental Politics since 1964 (Seattle, WA, 2012), ch. 5. Theodore Catton, Inhabited Wilderness: Indians, Eskimos, and National Parks in Alaska (Albuquerque, NM, 1997).

${ }^{13}$ Chad Montrie, To Save the Land and People: A History of Opposition to Surface Coal Mining in Appalachia (Chapel Hill, NC, 2003).

${ }^{14}$ Liz Crampton, "Race and Class Privilege in the Environmental Movement," Pachamama Alliance, Sep. 19, 2012, https://news.pachamama.org/news/race-and-class-privilege-in-the-environmental-movement (accessed Jun. 6, 2017). Park and Pellow, Slums of Aspen, 13.

${ }^{15}$ Roderick Nash, Wilderness and the American Mind (New Haven, CT, 1967).

${ }^{16}$ Stephen Fox, The American Conservation Tradition: John Muir and His Legacy (Madison, WI, 1981).
} 
transformation of the United States, driven by the rise of an increasingly prosperous middle class that gave new value to the environment as an amenity characterized by scenic beauty and ecological health. ${ }^{17}$ The most notable exception was Robert Gottlieb's scholarship. His 1993 book, Forcing the Spring, argued for a broader and more inclusive approach to the history of American environmentalism that saw important roles for industrial hygienists, such as Alice Hamilton, union leaders, such as Tony Mazzochi, and environmental justice advocates, such as Dana Alston. ${ }^{18}$ By then, however, the narrow understanding of the origins and consequence of American environmentalism rooted in a wilderness tradition and suburban concerns-not the work place or urban centers-had been etched in the scholarly and popular imagination.

Yet, that narrow understanding of environmentalism would likely have surprised many of the people who organized the first Earth Day. The closest the environmental movement came to a large-scale social movement was in the early 1970 s, when some twenty million Americans took part in Earth Day activities. ${ }^{19}$ Denis Hayes, the lead organizer, warned, "We are systematically destroying our land, our streams, and our seas. We foul our air, deaden our senses, and pollute our bodies. And it's getting worse." ${ }^{20}$ Walter Reuther, the president of the United Auto Workers, was a leading proponent of environmental reform, both helping to fund and speaking on Earth Day. He saw unions as champions of environmental reform, both inside and outside of factories. ${ }^{21}$ Edmund Muskie, Maine's Senator and Congress's leading environmental champion, put the point plainly on Earth Day: "Those who believe that we are talking about the Grand Canyon and the Catskills, but not Harlem and Watts are wrong." His aspiration was a society that "will not tolerate slums for some and decent houses for others, rats for some and playgrounds for others, clean air for some and filth for others." 22 Marvin Gaye's 1971 hit single, "Mercy, Mercy Me (The Ecology)," captured the range of issues that inspired those protests: oil spills, air pollution, heavy metal contamination, nuclear fallout, and population growth. Notably, old-guard conservation groups like the Wilderness Society and Sierra Club, which had made their names fighting for parks and wilderness before the 1970s, had little formal role in shaping the activities on Earth Day or the congressional agenda in the early 1970s. In Environmental Action's compilation of fifty-three Earth Day speeches, the term "pollution" appears ninety times, the term "city" fifty-four times, and the terms "poor" and "poverty" twenty-four times. In contrast, "wilderness" and "national park" appear a total of thirteen times. $^{23}$

Despite Muskie's speech, and as black scholars and leaders warned in the early 1970s, national discussions of environmentalism often had little to say about race or inequity in American society. ${ }^{24}$ Instead, what often distinguished the environmental movement in the early 1970s was the assertion that all Americans were equally dependent upon the environment, responsible for its degradation, and vulnerable to pollution. Although Americans were hardly equal in that respect, a wide array of Americans in the 1970s, whether white or non-white,

\footnotetext{
${ }^{17}$ Samuel Hays, Beauty, Health, and Permanence: Environmental Politics in the United States, 1955-1985 (New York, 1987).

${ }^{18}$ Robert Gottlieb, Forcing the Spring: The Transformation of the American Environmental Movement (Washington, DC, 1993).

${ }^{19}$ On the history of Earth Day and its legacy, see Adam Rome, The Genius of Earth Day: How a 1970 Teach-In Unexpectedly Made the First Green Generation (New York, 2013).

${ }^{20}$ Denis Hayes, "The Beginning," in Earth Day-The Beginning, ed. Steve Cotton (New York, 1970), i-iii.

${ }^{21}$ Chad Montrie, The Myth of the Silent Spring: Rethinking the Origins of American Environmentalism (Berkeley, CA, 2018), 3-4. Josiah Rector, "Environmental Justice at Work: The UAW, the War on Cancer, and the Right to Equal Protection from Toxic Hazards in Postwar America," Journal of American History 101, no. 2 (Sep. 2014): 480-502.

${ }^{22}$ Edmund S. Muskie, “A Whole Society," in Earth Day_The Beginning, 91-92.

${ }^{23}$ Cotton, Earth Day-The Beginning.

${ }^{24}$ On this point see David Stradling and Richard Stradling, Where the River Burned: Carl Stokes and the Struggle to Save Cleveland (Ithaca, NY, 2015), ch. 6.
} 
wealthy or working class, Republican or Democrat, saw an urgent need to address environmental ills that threatened the environment and public health. Emphasizing the public's shared vulnerability to environmental degradation was a powerful political strategy for the nascent environmental movement. It helped catalyze one of the most extraordinary bursts of legislative activity in modern American history: the National Environmental Policy Act, the Clean Air Act, the Clean Water Act, the Endangered Species Act, the Safe Drinking Water Act, and the Toxic Substances Control Act, among other laws, all passed between 1970 and 1976 with strong bipartisan support. Underlying these laws was the assumption that all Americans had, as the legislative language of the National Environmental Policy Act set forth, a right to a "safe, healthful, productive, and aesthetically and culturally pleasing surroundings." The clean air and water acts generally required uniform, national health-based standards, without regard for economic costs. The Clean Water Act aimed to eliminate discharges of pollutants to waterways by the mid-1980s. In short, for many environmentalists and political champions, like Muskie, the goal was not to clean up the environment for a few Americans, but the expectation that it could be cleaned up for all Americans.

Critics of the so-called mainstream American environmental movement would note that in emphasizing a common interest in environmental protection, the environmental movement often drew attention away from the ways in which race, class, and prejudice shaped the lived experience of inner-city residents, blue-collar workers, and minorities most vulnerable to environmental pollution. But the rhetorical emphasis on a shared interest in the environment was not empty. One of the most important legacies of American environmentalism is its role in contributing to improvements in the quality of the environment and public health for many, if not all, Americans. Between 1967 and 2006, the number of young children with high lead levels in their bodies dropped from more than 80 percent to fewer than 3 percent. The most recent analysis of national survey data reveals continued declines in blood lead levels between 1999 and 2014 for all Americans, irrespective of economic status, race, or ethnicity. ${ }^{25}$ By 2010, the benefits of the Clean Air Act were estimated at \$1.3 trillion annually, largely because of hundreds of thousands of avoided premature deaths due to reduced particulate emissions. ${ }^{26}$ A 2018 study demonstrated that the burden of particulate emissions continued to decline sharply for all Americans, irrespective of race or income level, between 2008 and $2014 .^{27}$ And, contrary to conventional wisdom, an analysis of the economic impacts of the Clean Air Act indicates that the benefits were progressive, benefiting poorer Americans twice as much as wealthier Americans. ${ }^{28}$ Longitudinal studies focused on youth living in southern California reveal significant gains in lung function since the mid-1990s due to improvements in air quality (even as air quality in the region continues to lag behind national standards), with the greatest gains for asthmatics and Hispanic children. ${ }^{29}$ The most comprehensive studies demonstrate that there have been significant declines in most major pollutants targeted by the Clean Water Act. ${ }^{30}$ In some places the improvements have been dramatic. Sewage released

\footnotetext{
${ }^{25}$ Man-Fung Tsoi et al., "Continual Decrease in Blood Lead Level in Americans: United States National Health Nutrition and Examination Survey 1999-2014," American Journal of Medicine 129, no. 11 (Nov. 2016): 1213-8.

${ }^{26}$ U.S. Environmental Protection Agency, "Clean Air Act from 1990 to 2020" (Washington, DC, 2011).

${ }^{27}$ Ihab Mikati et al., "Disparities in Distribution of Particulate Matter Emission Sources by Race and Poverty Status," American Journal of Public Health, 108, no. 4 (2018): 480-5.

${ }^{28}$ Antonio Bento, Matthew Freedman, and Corey Lang, "Who Benefits from Environmental Regulation? Evidence from the Clean Air Act Amendments," Review of Economics and Statistics 97, no. 3 (July 2015): 610-22.

${ }^{29}$ W. James Gauderman et al., “Association of Improved Air Quality with Lung Development in Children,” New England Journal of Medicine 372, no. 10 (Mar. 5, 2015): 905-13.

${ }^{30}$ David A. Keiser and Joseph S. Shapiro, "Consequences of the Clean Water Act and the Demand for Water Quality" (working paper, Yale University, Jan. 2017), http://www.econ.yale.edu/ js2755/CleanWaterAct_KeiserShapiro.pdf (accessed Nov. 1, 2017).
} 
to the Chattahoochee in Atlanta has been reduced by 99 percent. Boston Harbor has once again become a hub of urban activity, development, and recreation. ${ }^{31}$

Citing such accomplishments-which are most compelling in the case of addressing air pollution-is not meant to discount the whiteness of the national environmental organizations, the environmental public health challenges that persist, or the inequities in how those risks are distributed. Poor communities and communities of color still bear a disproportionate burden of polluted air, water, and toxic waste as demonstrated by high-profile issues, such as leadpoisoned drinking water in Flint, Michigan, the fight against the Dakota Access pipeline, and scholarly research. For instance, the 2018 study that shows the continued reductions in particulate matter exposure for all Americans also demonstrates the persistence of an alarming gap in exposure levels for whites compared to non-whites. ${ }^{32}$ But highlighting the broader legacy of environmental gains is meant to challenge any assertions that, as a column in Grist magazine recently put it, the history of environmentalism is one dominated by "large environmental organizations ... mostly run by well-off white people concerned about conserving critters and our country's natural beauty, not the health and welfare of its people." ${ }^{33}$ Not only does that statement misread the scope and consequence of American environmentalism, it also ignores the extent to which this legacy of environmental accomplishment transcends the mainstream environmental movement.

Starting with Gottlieb's Forcing the Spring, and accelerating in the past decade, a more recent body of historical scholarship has begun to focus on the heterogeneous, local origins of American environmental concerns, which sometimes followed the hierarchies of race and class, but were not entirely limited by them. This more recent literature highlights a broad array of movements for environmental reform that joined diverse activists and issues together in ways that confound the usual story of American environmentalism. The reach of environmental concern extended well beyond parks and wilderness or Rachel Carson and the suburbs to include urban activists fighting lead pollution in Baltimore and union members fighting air pollution in Missouri's Lead Belt, autoworkers concerned about cancer risks in the workplace, migrant workers opposing pesticide use in the Central Valley, inner-city blacks pressing for beach access in wealthy suburbs, and coalitions of rural westerners and environmentalists focused on land reform. These histories often highlight how environmental reform could both follow and reinforce the contours of inequity in American society, but also moments when efforts toward reform transcended such divisions. ${ }^{34}$ As the historian Benjamin Johnson has suggested, we need more histories that both explain how modern environmentalism has "perpetuated race and class hierarchies" and advanced "real and lasting environmental

\footnotetext{
${ }^{31}$ Jeff Inglis et al., "Waterways Restored: The Clean Water Act's Impact on 15 American Rivers, Lakes and Bays" (Washington, DC, 2014), https://environmentamerica.org/sites/environment/files/EA_waterways_scrn.pdf (accessed May 21, 2018).

${ }^{32}$ Mikati et al., "Disparities in Distribution of Particulate Matter Emission Sources," e3.

${ }^{33}$ Nikhil Swaminathan, "The Unsustainable Whiteness of Green," Grist, Jun. 20, 2017, http://grist.org/feature/ the-unsustainable-whiteness-of-green/ (accessed Nov. 1, 2017).

${ }^{34}$ For an excellent survey of the broader roots of environmentalism, see Montrie, The Myth of Silent Spring. More generally, see Hurley, Environmental Inequalities; Chad Montrie, To Save the Land and People; David Stradling, The Environmental Moment, 1967-1972 (Seattle, 2012); Jennifer Thomson, "From Wilderness to the Toxic Environment: Health in American Environmental Politics, 1945-Present" (Diss., Harvard University, 2013); Christopher C. Sellers, Crabgrass Crucible: Suburban Nature and the Rise of Environmentalism in Twentieth-Century America (Chapel Hill, NC, 2015); Cody Ferguson, This Land Is Our Land: Grassroots Environmentalism in the Late Twentieth Century (New Brunswick, NJ, 2015); Andrew Kahrl, "Fear of an Open Beach: Public Rights and Private Interests in 1970s Coastal Connecticut," Journal of American History 102 no. 2 (2015): 433-62; Erik Loomis, Empire of Timber: Labor Unions and Pacific Northwest Forests (Cambridge, UK, 2016); Rector, "Environmental Justice at Work."
} 
improvements." ${ }^{35}$ In short, the time has come to revisit the usual history of the modern environmental movement-including the "mainstream environmental movement" and the "environmental justice movement"-in ways that resist reductionist narratives and engage with the complexities, shortcomings, and, not least, the successes of a broader and more inclusive American environmental tradition. As Chad Montrie has argued, "much of what we call the 'environmental movement' in America is hobbled by the story we tell about its origins." 36 To fully understand the reach of environmentalism, we need to better understand how it originated in the activism of workers, minorities, and immigrants-not just wilderness-loving activists or white suburbanites. Such work is imperative, particularly at a moment when the nation's core environmental laws are once again at risk and pressing challenges loom on the horizon.

James Morton Turner is an associate professor of environmental studies at Wellesley College where he teaches courses on United States environmental history, politics, and policy. He is author of The Promise of Wilderness: A History of American Environmental Politics since 1964 (Seattle, 2012) and co-author of a forthcoming book titled The Republican Reversal: Conservatives and the Environment from Nixon to Trump (Cambridge, MA, 2018).

\footnotetext{
${ }^{35}$ Benjamin Heber Johnson, Escaping the Dark, Gray City: Fear and Hope in Progressive-Era Conservation (New Haven, CT, 2017), 4.

${ }^{36}$ Montrie, The Myth of Silent Spring, 158-9.
} 